\title{
GEOPOLITYCAL CONDITIONS OF DEVELOPMENT CARTOGRAPHY IN SAFETY COMMUNICATIONS
}

\author{
Dariusz DRZEWIECKI, PhD \\ Department of National Security \\ Geostrategy and Geography Section \\ National Defense University Warsaw, Poland
}

\begin{abstract}
In this paper, the development of cartography is synthetically presented in a historical context, from the first ideas on the planet to the modern methods of data collection, processing and display of digital media. In the last section, three examples of geoportals areas are given to present this technique's possibilities in the second decade of the twentyfirst century.
\end{abstract}

A non-random sample of geoportals was chosen because they represent transportation, an important and furiously growing field of modern civilisation.

The examples of planetary space namely in the area of land, sea and air are correctly presented.

Keywords: map, travelling, cartography, history, reference ellipsoid, geoportal, geospatial, geovisualisation

\section{Introduction}

Along with the progress of civilisation, man has tried to understand and imitate nature for centuries, but the achievements that have no counterpart in the development of other species are an important contribution to the development of civilisation of our species. 
One example is the scientific discipline called cartography and the source of the research that is maps. They allow you to take a look at our planet and can create images of different sections, presenting nature, economy, culture, and history, showing the precise location and the phenomenon that we often cannot see with the "naked eye”.

Geographical maps are particularly commonly used. They represent different phenomena, not through the photographic image, but through symbols and mapping, the spatial forming of real size models, abstract or anticipated, revealing their variability and development in the course of time.

\section{Concept Maps and History Cartografhy}

The term map is derived from the Latin word sitemap, which in translation means reducing generalisation or, more precisely, a spatial image plane.

A literal translation of the term sitemap is limited to the presentation of the surface area of the Earth and would be true of the photographic image, but the content of the modern map covers a variety of natural phenomena, the physical size and the political and socio-economic. Therefore, modern geographical maps can be described as a reduced mathematically defined graphically-character representation of the Earth's surface on a plane, clearly orienting the spatial position of objects, natural phenomena and social-economic conditions in the area.

\section{Historical background of cartography}

The beginnings of a scientific discipline called cartography, dealing with maps, methods of their preparation, copying and use dates back to ancient times. Graphical presentation of the area at that time went beyond politics; it was an expression of contemporary ideas about the organisation and appearance of the universe. It documented visions and ideas about the philosophy of the ancient world. Considering cartography as a science should start from the achievements of ancient Greece. The first works are related to Anaximander of Miletus 
(c. 550 BC), who developed a map with the characteristic shape of a circle, covering an area of the then known world, including the Mediterranean, the Black Sea, which is an area from Kałkaz up to Gibraltar. The central point was the holy city of Delphi. Anaximander's successors continued their work together with complementing messages discovering new previously unknown areas. Herodotus of Halicarnassus (c. $450 \mathrm{BC}$ ) collected and systematised existing knowledge, releasing three parts of the world: Europe, Asia and Africa. He described many ancient cities in Babylonia, Persia, and those located in the delta of the Nile. He reported the first descriptions of the lands in the northern part of Europe. Plotting maps based on mathematical calculations can be attributed to the times of Alexander the Great (c. 320 BC), in which detailed maps of new territories were plotted along with the making of further conquests, drawn up by special officials accompanying the army. The assumption at the time of the Alexandrian school influenced the rapid development of many scientific disciplines, including astronomy, geodesy and cartography. Then earlier work of Pythagoras and Aristotle led to the belief that the earth is spherical, and their students prepared a first geographic coordinate system used for the geographical location of ancient cities and roads. Maps in the days of the Greeks therefore presented a fairly accurate location of lands and seas, and in approx. 150 BC, Molos, librarian of the King of Pergamum, constructed the first known globe, confirming the increasingly widespread belief in the sphere of the Earth. But the greatest progress in the development of this discipline in ancient times is associated with Claudius Ptolemy (90-160 AD). He was the first scholar to point to a location on the Earth using knowledge of astronomy. He established a number of conventional signs, outlined the principles of generalisation, introduced a system of orientation maps in the north, and developed theoretical principles of projection maps and globe structures. Maps were created using conical projection, using a projection called homotetyc. His views on the construction of the world strengthened the geocentric view for many centuries, which was only overthrown by Nicolaus Copernicus. His expertise has been included in many publications, including the most famous thirteen volume work „Syntaksis”.

The legacy of the Greeks took over the Roman Empire, which used maps mainly for administrative and military purposes. The $1^{\text {st }}$ century $\mathrm{BC}$ accounts for the peak power of the empire, when, as a result of winning wars, it mastered almost all of Southern Europe, Western Europe, and much of Africa and Asia. Control 
over such a vast area determined the development of geographical knowledge and maps became the primary source of information during the journey, and a useful tool for the preparation of itineraries (from Lat. - Plan road travel journal). When discussing ancient times, it is impossible not to mention the achievements of Chinese or Arab cartographers. However, many of the achievements of local scientists got to Europe very late, even though they contributed to the expansion of Europeans to unknown lands and continents. The origins of early Chinese cartography are dated c. 2000. BC The rules for levelling the type used on maps and the cartographic grid scale were developed in China. The Chinese were the first to come to know the principle of the compass, which used orientation in the field. Chinese maps were initially published on wood and silk. Afterwards, the invention of paper became the basic material for their preparation. Unfortunately, none of the old Chinese maps has survived. In contrast, knowledge about the appearance and methods for their preparation derive from written sources, including the so-called. Chinese geography (Likurgu). The Arabs employed the knowledge of Chinese and Greek cartographers. The Arab cartography bloom coincides with the period of their greatest conquest, when Muslims ruled over a significant part of the world from India through the northern part of Africa, and part of the Iberian Peninsula in Europe. Unfortunately, the limitations of the Koran bans prohibiting graphical presentation of the items were the reason that the most accurate transmission was made in the form of a narrative.

Graphic Maps were schematic and simplified, showing the complex contours of the land in the form of schematic straight or circular lines, and deviated significantly from reality. The Middle Ages in Europe were characterised by a significant neglect of science, especially in mathematics and astronomy, and, thus, cartography. The achievements of the ancient period were forgotten, mainly as a result of the fight against the Church's view of the sphere of the Earth. Medieval maps have no cartographic grid or scale, the outlines of continents are wrong, and the descriptions sparse and disordered. In contrast, they contain a lot of graphic images of ancient and biblical figures. A classic example is the thirteenth century map located in Hereford Cathedral, England (Fig. 1). 


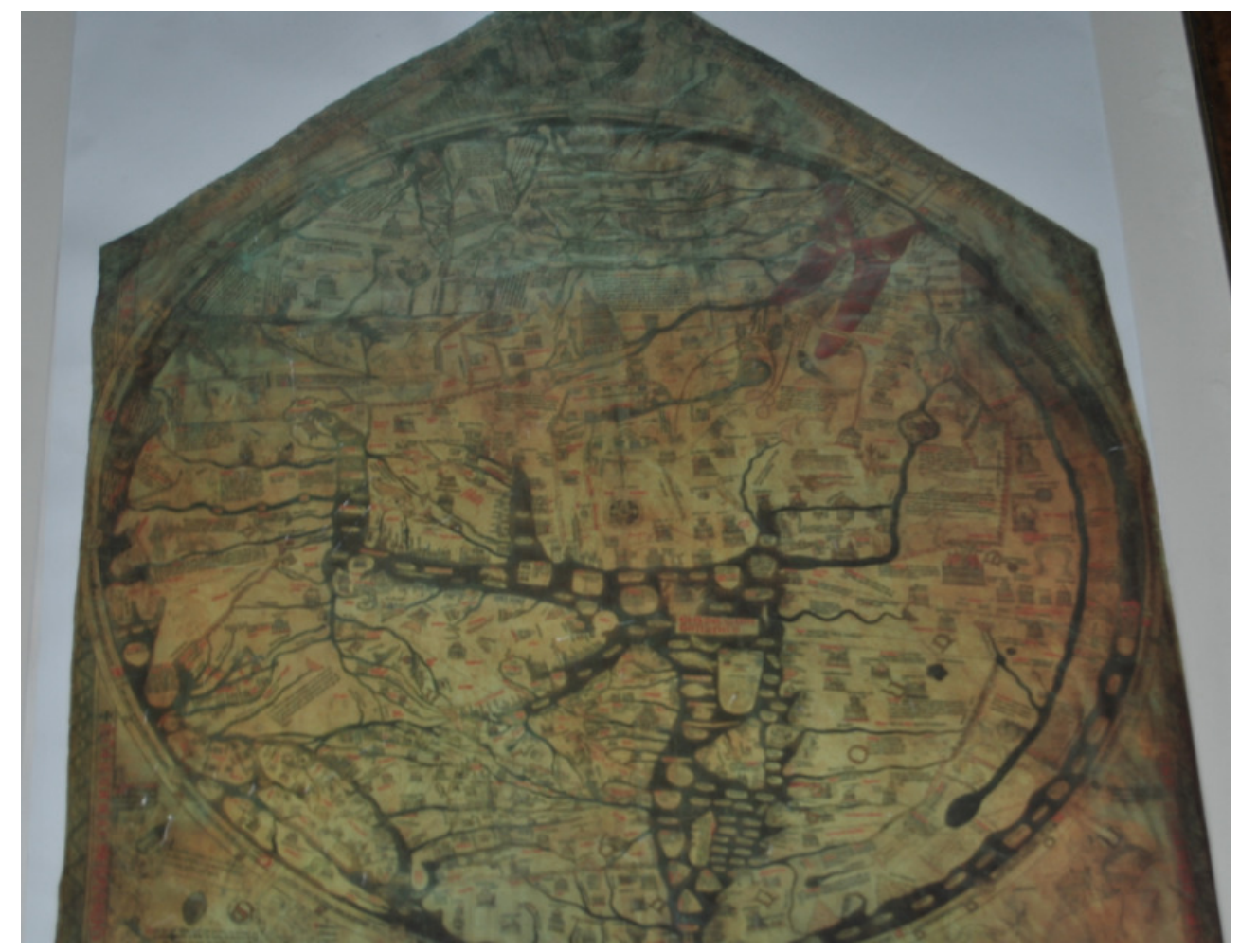

Source: Private documentation, Dariusz Drzewiecki

\section{Figure 1. Map of the thirteenth century world. Hereford, England}

Attributable to the end of the Middle Ages, a time of great travellers, such as: Carpini (persons 2), Rubruk (persons 3) and Marco Polo, was marked by the formation of a better known new world map. At this time, for the first time in the history of cartography, the name of Poland appears. However, completely different views on science were formed during the Renaissance.

As a result of the great geographical discoveries, including Christopher Columbus' expeditions, a rapid breakthrough in the development of the natural sciences was made. Columbus studied the writings of ancient writers such as Seneca and Aristotle and analysed the maps available to him, including the Florentine astronomer Toscanelli (1397-1482) (persons 1), which confirmed his belief in the ability to reach India by sea. Erroneous estimates of the size of the globe and, thus, the time a naval expedition to India would take resulted in the discovery of an unknown continent at that time - America. 
In the Renaissance, a revolution in the field of mathematics, astronomy and geographical sciences took place. Circumnavigation of the globe by Ferdinand Magellan had established views on the shape and size of the Earth. Expeditions of other explorers contributed to the creation, in the sixteenth century, of the maps made by the Portuguese cartographer, Diego Ribeiro (1518-1532) (persons 4), in which the world is presented as a truer distribution of lands and oceans (Fig. 2).

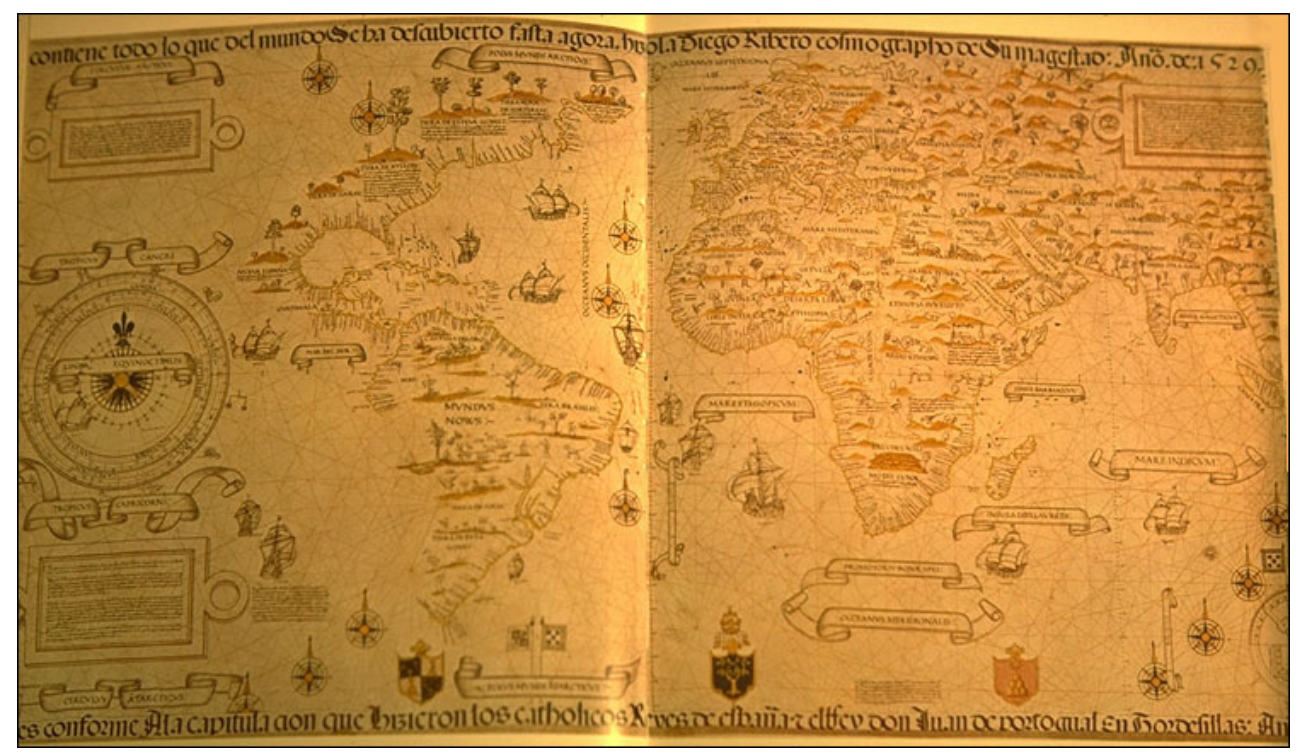

Source: wikipedia.org/Wiki/Diogo_Ribero.

Figure 2. Map of the world made by Diego Ribero, 1529

Among the cartographers can at this time were the most prominent scholars of the era of Leonardo da Vinci, who developed the globe much more accurately than those produced in ancient times. Among them was one of the greatest scholars of the Renaissance, Gerard Mercator (1512-1594), the Flemish mathematician, geographer and astronomer. He wrote about cylindrical projection, more commonly known as the Mercator projection, which is one of the key mappings also used in the preparation of modern geographical maps. The definitive break with the flat Earth view determined the development of mathematical sciences in this geometry. Maps with smaller areas were created, based on accurate surveying using triangulation and an equidistant grid. 


\section{Cartography on Polish lands}

The bloom in Polish cartography fell at the end of the sixteenth and the first half of the seventeenth century. It involved the lively military activities during this period and the plans to expand the Polish zone of influence in the north and east during the reign of King Sigismund III and Władysław IV. Polish rulers gathered and systematised information on areas which were theatres of war. Outstanding engineers were employed in the construction of fortifications and communication infrastructure and drew up descriptions of the most prominent cartographers' territorial maps useful in the development of the military. Władysław IV of Poland had a unique maritime map showing the mouth of the Vistula, Hel Peninsula and the Bay of Puck. The most famous cartographers of the time included a French officer in the service of Polish King named Guillaume le Vasseur de Beauplan (1600-1673). He led engineering work in Ukraine, Podolia and Volhynia, and took part in setting the Polish-Muscovite border after the signing of the peace in Polanów. He collected information which was used on maps of the middle and lower reaches of the Dnieper and the southern part of Ukraine.

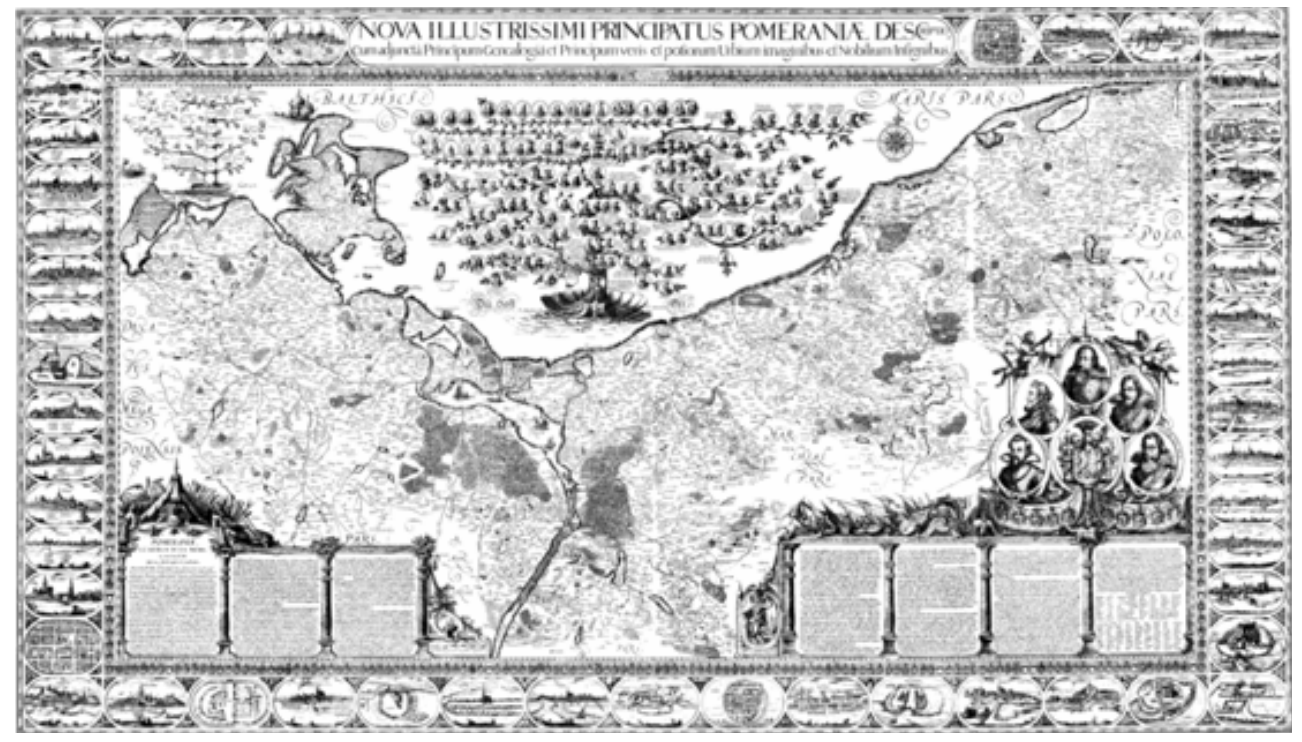

Source: wikipedia.org/Wiki/Wielka_Mapa_Księstwa_Pomorskiego.

Figure 3. Great Map of the Duchy of West Pomerania by Eilhard Lubinus was drawn between 1610-1618 
A perfect example of the achievements of Renaissance cartography is a map of West Pomerania (Fig. 3), developed by the German mathematician and cartographer, Eilhard Lubinus (1565-1621) (persons 5). The entire area of the Duchy of Pomerania from the early seventeenth century andthe islands of Rügen, Uznam and Wolin are covered on the map. The map is framed by a laned border. In the outer "border", views of 49 Pomeranian towns can be seen (some of them the work of Jan Wolfart) and 353 coats of arms in the inner border along with the names of the representatives of the Pomeranian nobility, arranged in alphabetical order. 22 positions are empty, because, despite reminders and requests from some families, the princes did not supply images of their coats of arms.

There are two family trees on the map. In the upper part of the left side is a tree relating to 19 Rügia princes, while in the top centre of the tree 157 Pomeranian dukes can be found. At the bottom right is a large coat of arms of Pomerania, and under it the separate arms of various regions which form its emblem. Around the coat of arms of Pomerania five portraits of Pomeranian dukes that were contemporaries of Lubinus. Below, on both sides of the map, on seven boards, the author gives a brief geographic - historical - economic description of Pomerania in Latin. On the left, in the last internal table, Lubinus put his own portrait with the measuring instruments that were used in the cartographic work. On the opposite side, we can see the image of Nicholas Geilkerckus the engraver.

Another important period in the development of Polish cartography was the second half of the eighteenth century. The mental rebirth of Polish society and political changes, including the partitions, became the reason for the increased interest in this discipline. For the most prominent figures of the period include Jabłonowski Alexander (1711-1777), co-founder and organiser of the work on the map of Poland and the Grand Duchy of Lithuania, forming the basis for the development of the atlas map of the "special” court geographer Charles Pertheesa (1739-1814) and edited by King of Poland, Stanislaus Augustus. Until 1795, 14 maps of provinces were designed in a descriptive manner (including the collection of measurement data, supplemented by the results of the site survey and astronomical observations), of which five were printed in graphical form. The late eighteenth century was characterised by the work of Polish cartographers in foreign countries, which was associated with the subsequent collapse of the partitions and the Polish state. 
The only Polish map which was established during this period wasthe geological map developed by Staszic. The rebirth of Polish cartography is thought to be associated with the character Eugene Romero (1871-1954), known as the creator of modern Polish cartography and was developed by the base of the image of the graphical presentation in force today. His disciples, later workers at the Military Geographical Institute, carried Polish cartography to the highest international level.

In the 1930s, Polish military maps, the popular "hundreds” (scale 1: 10000) and "fifty" (scale 1: 50,000) had no equal.

The development of Polish cartography in the times of the People's Republic was associated with the work of research institutes and departments of geography at universities. Unfortunately, this was monopolistic and restricted by the activities of the National Cartographic Publishing House and made no significant contribution to the development of Polish cartography during this period. The basis of modern Polish cartography, like global satellite measurement data, is supplemented with high-quality aerial and satellite images.

Editorial works use modern graphic techniques based on digital technology.

\section{Reference ellipsoid}

The transition from the physical form of the solid Earth to its projection on the plane (map), is the projection of the surface, which is a mathematical model of a geometrical figure (approximately engaging the surface of the planet) on a flat surface.

In practice, we use three different geometric shapes to approximate the Earth:

- The natural and physical surface of the Earth;

- The surface called the geoida;

- The surface of a sphere or spheroid (depending on the scale of the map). From the mid eighteenth century, a measure of the model of the Earth, due to the ease of mathematical description, proved to be the most useful area of an ellipsoid of revolution. 
A more accurate designation of the Earth's ellipsoid parameters occurred at the same time as the installation of measuring equipment on artificial satellites. The data obtained from satellites with measurements taken on the ground led to the appointment of an ellipsoid closest to the actual shape of the earth. The use of artificial satellites allowed the creation of geodetic systems worldwide (World Geodetic System - WGS), leading to the introduction in 1972 of the standard system WGS-72 (still used in surveying tasks).

\begin{tabular}{|l|l|l|l|}
\hline \multirow{2}{*}{ Reference ellipsoid } & \multirow{2}{*}{ Year determined } & \multicolumn{3}{|l|}{ the dimensions of the drive shaft in [m] } \\
\cline { 3 - 4 } & & large & small \\
\hline WGS-72 & 1972 & $6378 \mathbf{1 3 5}$ & 6356751 \\
\hline WGS-84 & 1984 & 6378137 & 6356752 \\
\hline
\end{tabular}

Table 1. Parameters of the ellipsoid WGS

Obtaining accurate data occurred with the introduction of the Global Navigation System GPS (Global Positioning System), which allowed for the development of a new ellipsoid WGS-84 (Table 1), which is still valid reference for cartographic mapping.

\section{Mapping of}

It is impossible to throw a spherical surface to prevent the creation of an image plane without distortion, because not all the known mapping is perfect. In practice, in the development of topographic maps, mapping was used to ensure equal angles with the least distortion distance. The mapping should be characterised by a simplicity of mathematical and geographical structure.

Mapping that meets the criteria is the universal transverse Mercator projection (UTM - Universal Transverse Mercator), preferred in developing topographic maps used by the most important state services.

Each cartographic mapping feature has the ability to construct a coordinate system which is an ordered sequence of numbers, determining the position of a point on a map. To determine the geographical coordinates of the cartographic 
grid applied, the grid forms a geographic coordinate system when the lines are orthogonal to one another and plotted at equal intervals form a flat rectangular coordinate system, and when the skeleton is created by lines of latitude and longitude.

In order to avoid ambiguity when determining the location of a point on the surface of the globe, Reported UTM, UPS, GEOREF (see glossary) are launched based on a flat rectangular coordinate system, enabling quick and clear communication of information in a variety of communication systems.

\section{Topography Maps}

The most commonly used maps to determine the location of an object, determine the distance between any points and determine the direction of walking, especially in areas with small anthropogenic changes that are included in topographic maps. They present the Single Convention notation and detailed descriptions of selected elements of the geographical environment, such as topography, hydrography, communication infrastructure, settlement areas, vegetation, etc. (Examples of applied topographical are contained in tab. 2).

They are characterised by their distinct mathematical and cartographic design, kilometre grid, distinctive graphic design and cut of a single sheet marked with a description for the frames. During the preparation and study of the analytical process of topographic maps, it is necessary to allocate them in order to make sense of the concept and the importance of the interrelationships of elements and phenomena contained within the topographic map so we can distinguish between several inseparable elements, such as:

cartographic representation - full information about the objects shown and natural phenomena and on the socio-economic characteristics, their interrelationships and the volatility or development (water, sculpture, vegetation, anthropogenic changes, political-administrative division, etc.)

mathematical matrix - showing geometric design rights and properties of cartographic visualisation, which include mapping of, scale, grid and geodetic 
coordinates. Auxiliary indications - information to help reading maps and the use of them (legend, measurement charts, information data, etc.).

Supplementary data - included in the vacant area within a frame (text and numerical data, diagrams, sections, etc.).

\begin{tabular}{|c|c|c|c|c|c|}
\hline 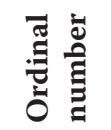 & $\begin{array}{l}\text { Symbol character } \\
\text { name }\end{array}$ & Symbol & : & $\begin{array}{l}\text { Symbol character } \\
\text { name }\end{array}$ & Symbol \\
\hline 1. & Railroad station & 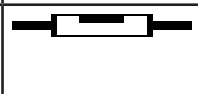 & 14. & Tall coniferous forest & 速道。 \\
\hline 2. & $\begin{array}{l}\text { Power line, electrical } \\
\text { cable overhead }\end{array}$ & -3 & 15. & Tall deciduous forest & of \\
\hline 3. & Motorway & $=---x$ & 16. & Tall mixed forest & olst \\
\hline 4. & Secondary Road & $\overline{\bar{\nu}}$ & 17. & The compact bushes & 8 \\
\hline 5. & Local Road & & 18. & Orchard & $\begin{array}{l}6900 \\
6900 \\
6000\end{array}$ \\
\hline 6. & Rural road & & 19. & $\begin{array}{l}\text { The dry and marshy } \\
\text { meadow }\end{array}$ & " $"$ " \\
\hline 7. & Forest road & ----- & 20. & Swamp & $\overline{\overline{\overline{\overline{ }}}} \overline{\overline{\overline{\bar{z}}}}$ \\
\hline 8. & Path & --- & 21. & Building & \\
\hline 9. & Fence & عس & 22. & Compact construction & Za \\
\hline 10. & Stream, river & בص= & 23. & A single farm & \\
\hline 11. & The series of trees & 00000 & 24. & Industrial plant & \\
\hline 12. & Gas station & $\boldsymbol{\tau}$ & 25. & Church & 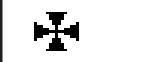 \\
\hline 13. & Transformer & & 26. & Forester & \\
\hline
\end{tabular}

Table 2. The most common cartographic symbols 


\begin{tabular}{|c|c|c|c|c|c|}
\hline 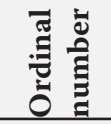 & $\begin{array}{l}\text { Symbol character } \\
\text { name }\end{array}$ & Symbol & 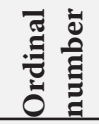 & $\begin{array}{l}\text { Symbol character } \\
\text { name }\end{array}$ & Symbol \\
\hline 1. & Low Pressure Centre & & 12. & Ice Pellets & $\bullet$ \\
\hline 2. & $\begin{array}{l}\text { High } \\
\text { Centre }\end{array}$ & & 13. & Freezing Rain & - \\
\hline 3. & Cold Front & $\Delta \quad \Delta$ & 14. & Drizzle & 9 \\
\hline 4. & Warm Front & ــــــــ & 15. & Freezing Drizzle & 99 \\
\hline 5. & Occluded Front & & 16. & Snow & \\
\hline 6. & Stationary Front & $\Delta$ & 17. & Snow Showers & \\
\hline 7. & Wind speed $[\mathrm{m} / \mathrm{s}]$ & 10 & 18. & Hail & \\
\hline 8. & Rain & ○ & 19. & Thunderstorm & \\
\hline 9. & Rain Shower & $\vartheta$ & 20. & $\begin{array}{l}\text { Thunderstorm and } \\
\text { Rain }\end{array}$ & \\
\hline 10. & Fog & & 21. & Blowing Snow & $\rightarrow$ \\
\hline 11. & Mist & & 22. & Hurricane & \\
\hline
\end{tabular}

Table 3. Selected cartographic symbols used on weather maps

\section{Spatial Information Systems}

In the second half of the twentieth century, there was progress in the field of visualisation of mapping images. This involves the creation of a digital map. Unlike the analogue map, whose history dates back thousands of years, its formation is related to the dynamic development of information technology and methods for creating, analysing and processing information and display using new means of visuals. A digital map contains information about the topological or geometrical relationships of selected elements of the space. A digital map is created in such a way that the base is oriented in topological geometry. This means that the points or lines having an index $\mathrm{X}, \mathrm{Y}$ and $\mathrm{Z}$ are defined in relationship to other objects 
having specified coordinates and are named in accordance with the descriptive database. A digital map can be built in different ways. Firstly, the source of the information may be surveying a field. Apart from this, there are those that obtain data are by photogrammetric methods (aerial) or remote sensing. The main digital map can also be created by digitising an existing analogue maps bar. The digital map is the main element of the Spatial Information System.

Visualisation affects how scientific research is routinely employed in many disciplines of science and its teaching purposes, and is sometimes conceived as a means of artistic expression. However, the greatest progress in the field of cartography in the last decades was marked by the development of methods of satellite location of objects on Earth. The first working satellite navigation system was established in the early 1960s . The NAVSAT, NNSS (Navy Navigation Satellite System) transit system was initially used by the US Navy to determine the position of a submarine's ballistic missile and lately also by surface ships, and was made available to civil users in 1967. It has been used, among other things, in navigation and for hydrographic and geodetic purposes. Satellites are placed in low polar orbit at an altitude of about $1100 \mathrm{~km}$ above the Earth's surface. The orbital period of the satellite around the Earth was approx. 106 minutes. To provide the global reach of the system a constellation of five satellites was needed. During normal operation of the system 10 satellites ( 5 up) were maintained in orbit. Because of its flaws, the Transit system was replaced by the Global Positioning System (GPS) and disbanded in 1996.

The Global Positioning System (GPS) - in fact NAVSTAR GPS (Global Positioning System - NAVigation Signal Timing And Ranging) - a satellite navigation system developed by the US Department of Defense, was extended across the entire globe. Its main task is to provide users with information about their location and to facilitate navigation on the ground and in areas with no reference points as reservoirs or deserts. The system consists of three segments (Fig. 4): - Space consists of 31 satellites (as of 16.12.2011 r.) Located on circular orbits with a slope of $55^{\circ}$ or $63^{\circ}$ to the plane of the equator. Circulation of the Earth by satellite takes 11 h $58 \mathrm{~min}$ (half day Star)

- Ground (control and monitoring stations on the ground),

- User (receivers). 


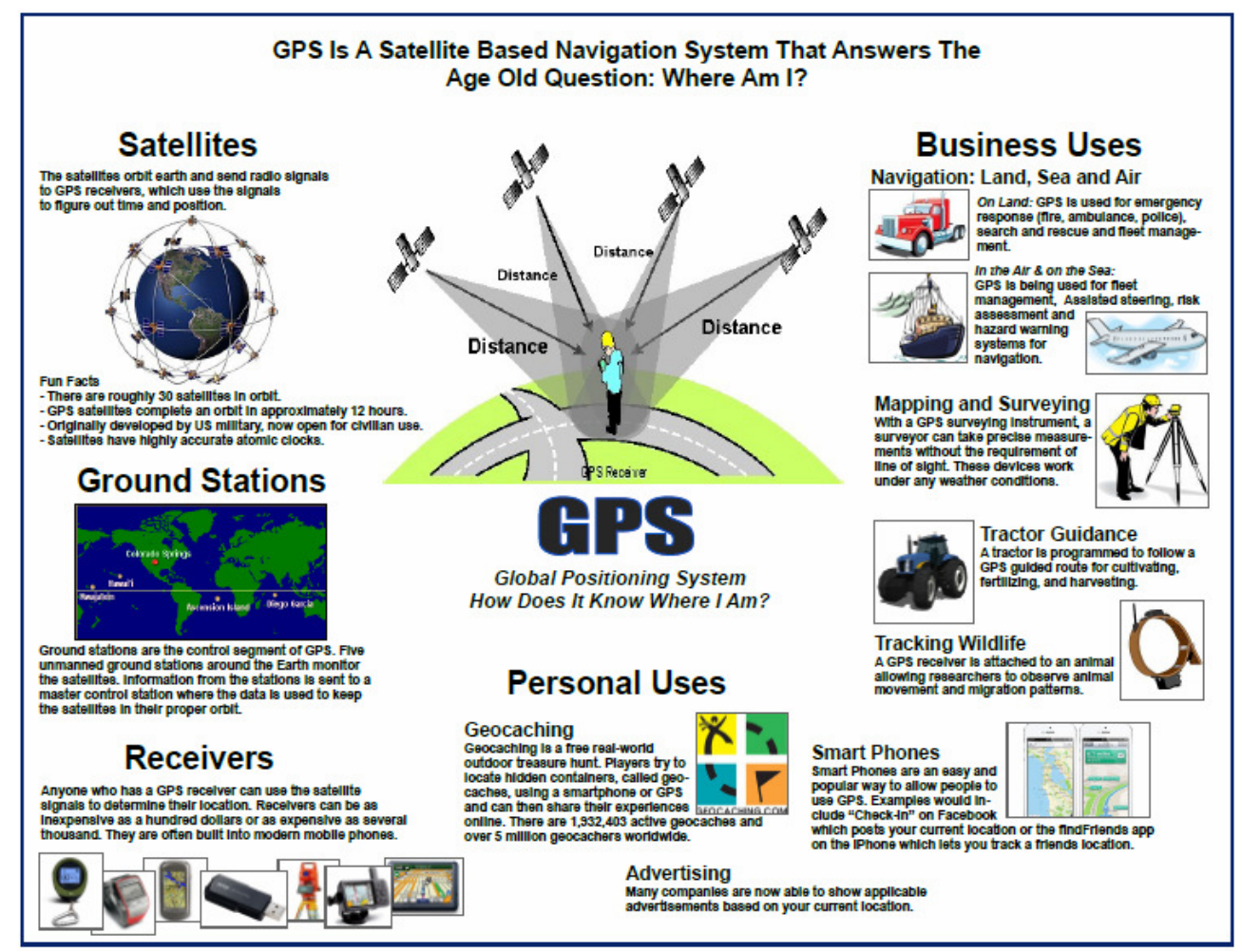

Source: http://www.countygp.ab.ca/assets/Community/Docs/gis_day_GPS.pdf.

Figure 4. A comprehensive Global Positioning System (GPS) scheme

The system works across the Earth, so that at any point of the globe at least four satellites can be seen. Satellites orbit after orbit at an altitude of about $20183 \mathrm{~km}$ above the Earth's surface. About 28 satellites are constantly active, and the rest are tested or excluded for technical reasons. The GPS receiver in the first phase updates this information in its memory and uses it thereafter to determine its distance from each satellite, for which the receiver is in range. A performing linear spatial Resection microprocessor receiver can calculate the geographical position (longitude, latitude and ellipsoidal height) and then give it to your chosen frame of reference - the standard is WGS 84, as well as the current GPS time with very high accuracy.

GPS is operated and managed by the US Department of Defense. Everyone can in principle use it - with a suitable GPS receiver. Such receivers are manufactured by 
independent commercial companies. The GPS system is free and so is expected to remain in line with the policy of the United States.

Geovisualisation A number of tools and techniques allow geographic information to be presented. They emphasise the mutual understanding of spatial relationships and data structures to allow their use in practice. Traditional maps are of limited usefulness because the symbols used are permanently associated with the elements of the site. Application of GIS to create digital, interactive cartographic mapping allows the sign to invest in separate layers, scale area and change the settings of their display. Combining several geovisualisation systems and networks of information exchange that is the Internet, makes it possible to illustrate the multi-dimensional space. On an ongoing basis, we can track the movement of any place on land transport (Fig. 5, 6), sea level (Fig. 7, 8) and air (Fig. 8).

Obecne położenie pociągów spółki Przewozy Regionalne odświeżane co 15 sekund, ostatnio o 15:11:40, źródło: http://kursowania.przewozyregionalne.pl/

Wypróbuj Mobilny Rozkład Jazdy

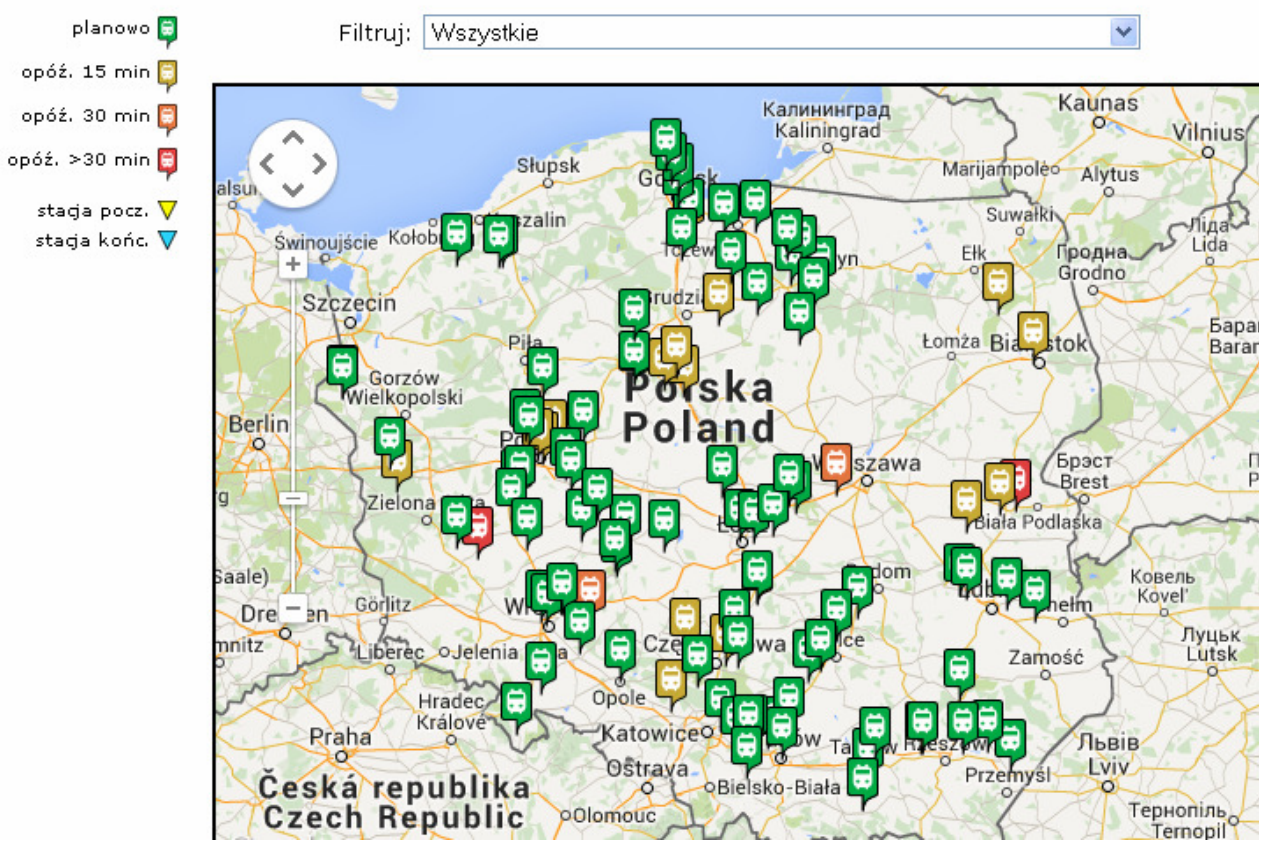

Source: http://mapapociagow.pl.

Figure 5. Position of the company trains in Regional Transport visualisation 

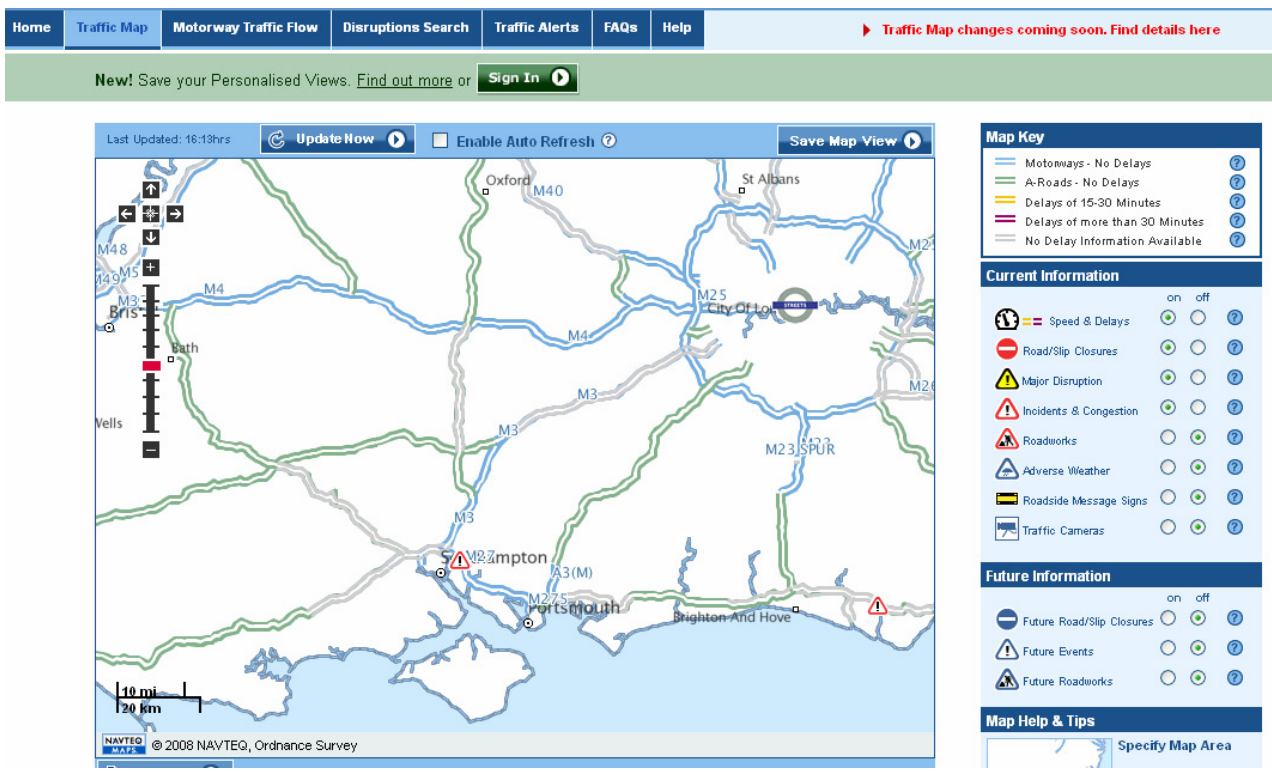

Source: http://www.trafficengland.com.

Figure 6. Situation on the motorways visualisation in the UK

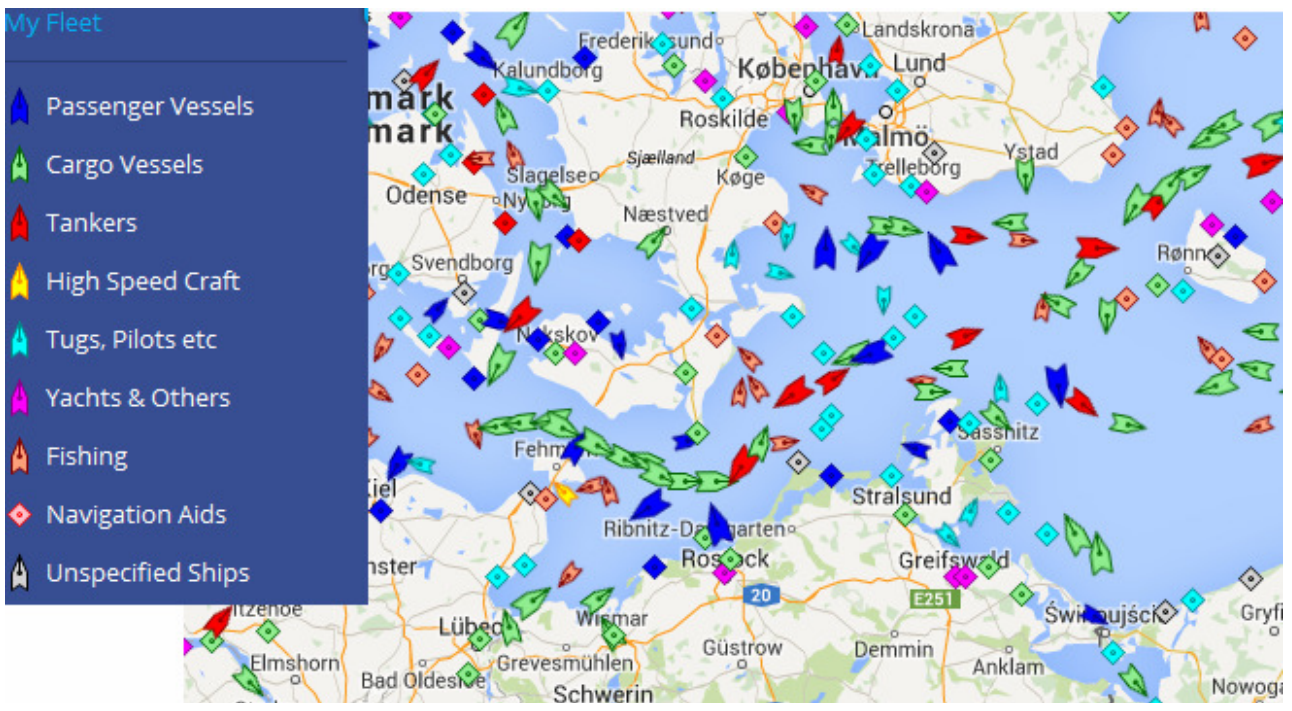

Source: http://www.marinetraffic.com/en/.

Figure 7. Vessel traffic visualisation (Danish straits area and Bay of Pomerania) 


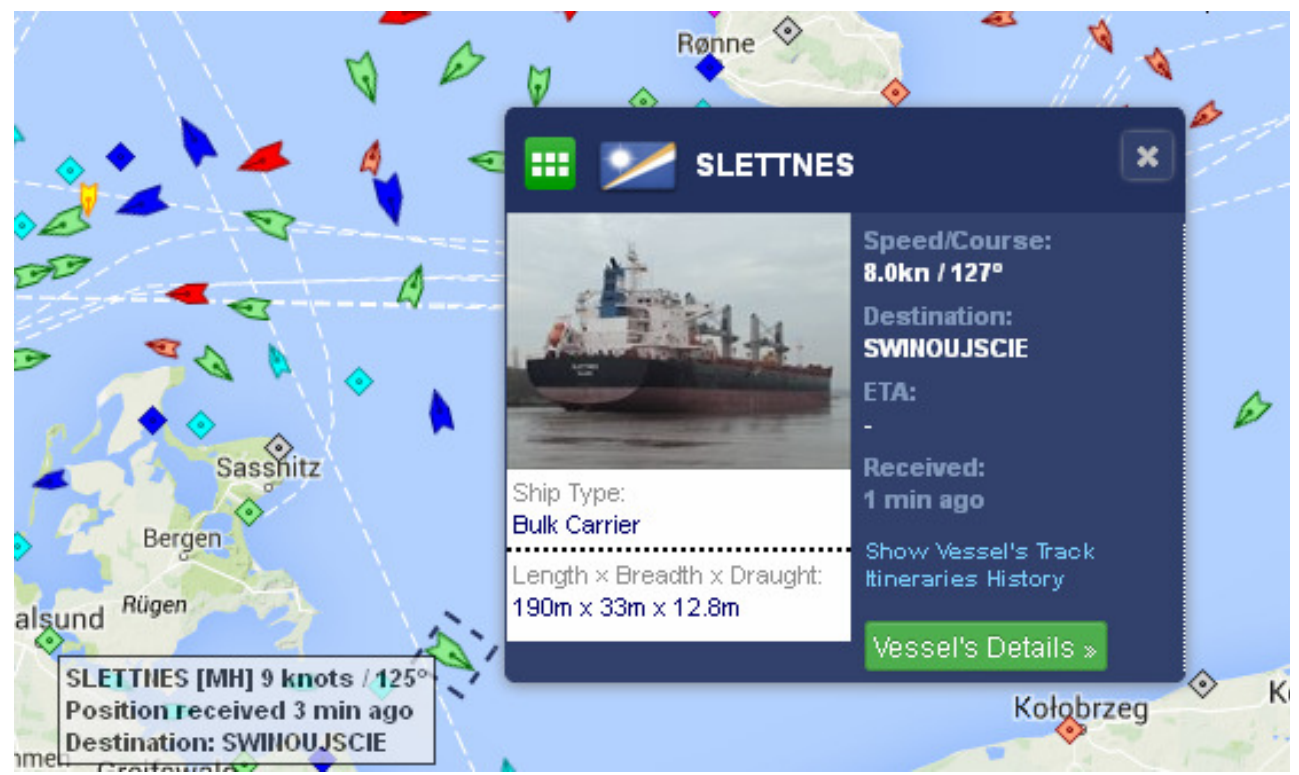

Source: http://www.marinetraffic.com/en/.

Figure 8. Vessel traffic visualisation - when you point the cursor, symbolic shipa receive a packet of information on the unit with the current exchange rate and the port of destination

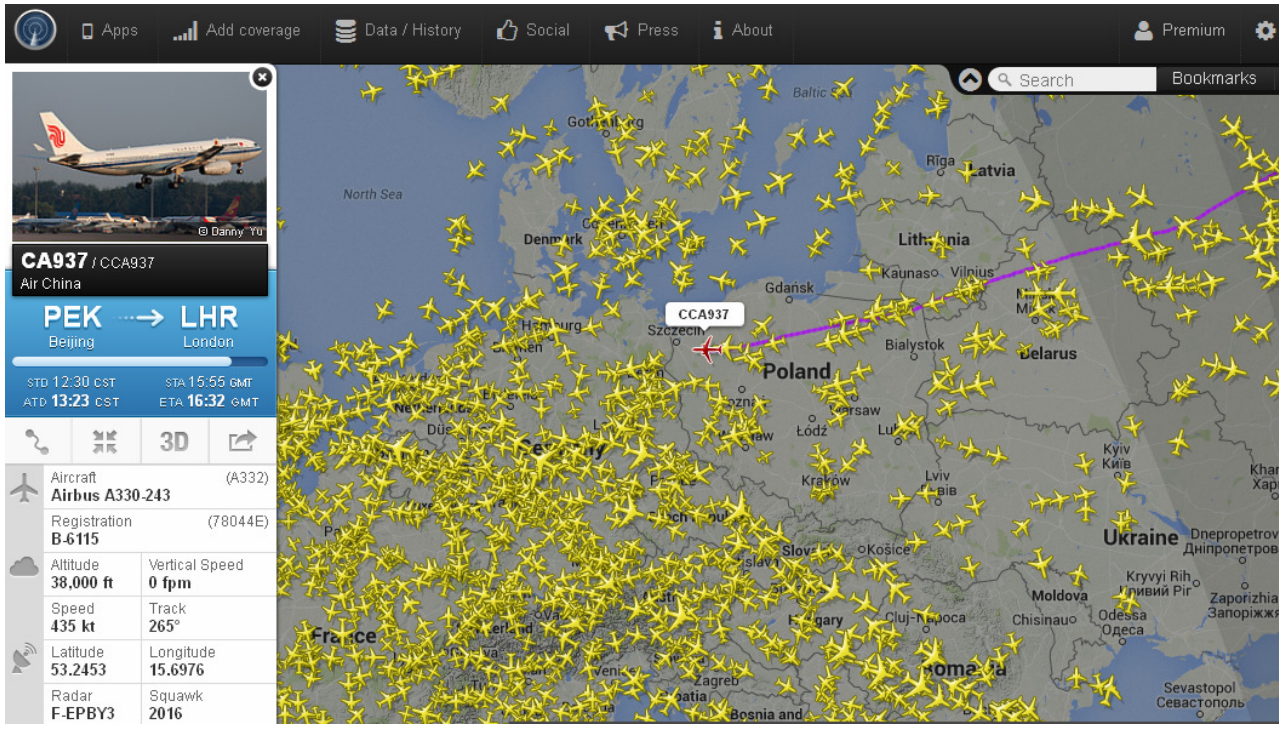

Source: http://www.flightradar24.com.

Figure 9. Aircraft movement visualisation (of central Europe region) - When you move your mouse over the symbol, the aircraft receive a packet of information for a given unit, along with the current flight route and destination airport 
Some examples of the use geovisualisation, widely discussed in the literature, are summarised below. In all cases, it represents easier management of content and makes it available at the same time to a number of interested parties.

- Forestry:Common software using GIS and Visualisation Toolkit (VTK) foresters monitor the number of processes taking place on their territories through a network, archaeology: In addition to the spectacular 3D simulation test sites and events, scientists have the ability to apply archaeological cataloguing not extracted yet,

- The study of the natural environment: the treatment of complex compounds occurring in nature is simpler when they can be combined according to specific criteria. Key decision precedes the initial forecast of the effects and tries to find alternatives

- Urban: solving problems related to the urban planning and architecture environment is supported by the computer; the results can be made available to all interested parties,

- Police: crime maps reflect the distribution in time and space of criminal phenomena for analysis by law enforcement agencies. A key element of the research is to follow guidelines on registration of incidents included in the standard CompStat. The use of GIS allows the presentation of this information in the form of maps, which can highlight particularly dangerous places (hot spots).

Glossary: UTM (UTM Reference System) is built using the UTM coordinate system. It is used to determine the location of points on the surface of the Earth, as the record, administered in orders and for reporting purposes. It was designed for the area of the globe between parallels $80^{\circ} \mathrm{S}$ and $84^{\circ} \mathrm{N}$.

UPS (Universal Polar Stereographic System) is built for the polar regions of the globe, is higher than $84^{\circ}$ north latitude and below $80^{\circ}$ latitude, which does not include the reporting system UTM

GEOREF (World Geographic Reference System) is built on the basis of the cartographic grid and various cartographic maps of the Earth's surface and used on maps on a scale 1:250 000 and smaller. It is used for determining and locating points and objects on the surface of the Earth; is used for commands and reporting purposes, and in developing the documents at higher levels of command. The system is used on a global scale, including in strategic land and sea operations. 
GIS (Geographic Information System) - an information system for entering, storing, processing and visualisation of geographic data, one of whose functions is to support the decision-making process. Each system consists of a GIS: geographic database, hardware, software and the developers and users of GIS.

Geoportal - web portal providing access to spatial data. The spatial data services and those operations that can be performed using computer software are contained in the spatial data sets or in the related metadata.

Metadatas - structured information used to describe a resource of information or information objects, providing detailed data on the attributes of resources or information objects, in order to facilitate finding, identifying, and managing these resources. Metadata can be divided by category as descriptive, structural and administrative.

Persons (based on the free encyclopedia and Encyclopedia Britannica ):

1) Paolo dal Pozzo Toscanelli (1397 - 10 May 1482) was an Italian astrologer mathematician, and cosmographer. Paolo dal Pozzo Toscanelli was born in Florence, the son of the physician Domenico Toscanelli. There is no precise information on his education and background. In 1894, Gustavo Uzielli claimed that Toscanelli studied at the University of Padua, but modern authors consider this pure conjecture.

2) Giovanni da Pian del Carpine, variously rendered in English as John of Pian de Carpine, (born c. 1180, Pian del Carpine?, near Perugia, Umbria-died 1 Aug 1252, Antivari [Bar], Dalmatia?), Franciscan friar, first noteworthy European traveller in the Mongol Empire, to which he was sent on a formal mission by Pope Innocent IV. He wrote the earliest important western work on Central Asia.

3) William of Rubruck (c. 1220 - c. 1293) was a Flemish Franciscan missionary and explorer. His account is one of the masterpieces of medieval geographical literature comparable to that of Marco Polo and Ibn Battuta. Born in Rubrouck, Flanders, he is known also as William of Rubruk, Willem van Ruysbroeck, Guillaume de Rubrouck or Willielmus de Rubruquis.

4) Diogo Ribeiro, also known as Diego Ribero, was a Portuguese cartographer and explorer who worked most of his life in Spain. He worked on the official maps of the Padrón Real (or Padrón General) from 1518-1532. He also made navigation instruments, including astrolabes and quadrants. 
5) Eilhard Lubinus (1565-1621) was a German Lutheran theologian and philosopher, also known as a classical scholar, mathematician and cartographer. He was an influence on Comenius. His actual name is Eilhard Lübben. Born in Westerstede in 1565, Lubinus was son of a pastor in the Duchy of Oldenburg. He studied at Leipzig and other universities, and in 1595 became Professor of Poetry in the University of Rostock. In 1605 he transferred to the Chair of Theology there. Phillip II of Pomerania in 1610 commissioned him to make a map of Pomerania. He died in 1621 in Rostock.

\section{Summary}

Man has always used a universal language to describe the world of cartography by drawing maps that were used for orientation in the field. Maps and technically advanced location means are currently used which GPS receivers are not always aware of or how advanced technical measures were used over the centuries for the presentation of the data. The era of dynamic development of the Internet and telecommunications networks plays an increasingly important role in spatial information infrastructure expansion. Currently, the geographical area defined by digital maps, which allows electronic access, is, for example, the ongoing project Geoportal2. It is a website that provides access to resources and services related to spatial data, especially the browse and search services. Given the territorial scope of the presented data, we can talk about Geoportal - at the central level (national geo) and at the regional level (county, city or municipal geoportals).

Although technical progress is changing the presentation of geographic information (instead of a sheet of paper, we use the image of the media more often), there is a traditional way to orientate in the field using the "paper sheet” which has for centuries been the easiest and most reliable. However, despite the undeniable advantages of traditional forms of presentation, contemporary geographical geoportals have a definite advantage over the traditional form of visual spatial image by adding another dimension that is the time, which, for example, is necessary to keep track of the selected objects in motion (sec. geovisualisation).

Anyway, no matter how technologically advanced cartographic presentation video relay is, the basic principles of data transformation and setting the symbolism of 
objects and phenomena is immutable. Therefore, it appears advisable to them to be accessible and synthetic, and perhaps readers are interested in this subject, especially since such a widely available product of human thought as the map counts as one of the greatest achievements of our civilisation.

\section{LITERATURE}

1. ArcanaGIS, jesień 2013, „Magazyn dla użytkowników oprogramowania ESRI”, APOGEO Sp. z o.o., Kraków

2. ArcanaGIS, zima 2013, „Magazyn dla użytkowników oprogramowania ESRI” ,APOGEO Sp. z o.o., Kraków

3. Drabek J., Piątkowski T., 1989, „1000 słów o mapach $i$ kartografii”, Wydawnictwa Ministerstwa Obrony Narodowej, Warszawa

4. Fariel R., Hinds R., Berey D., Barr B., 1987, "Earth Science”, Addison-Wesley Publishing Company, Inc

5. Goodchild, M.F., P. Fu, and P.M. Rich. 2007, "Geographic information sharing: the case of the Geospatial One-Stop portal", Annals of the Association of American Geographers

6. IBM i2 Analyst's Notebook, 2012, Copyright IBM Corporation

7. Janiszewski F.,- 1988, „Instrukcja dla stacji meteorologicznych”, Instytut Meteorologii i Gospodarki Wodnej, Wydawnictwa Geologiczne, Warszawa

8. Narkiewicz J., 2003, „Globalny System Pozycyjny GPS”, Wydawnictwa komunikacji i Łączności sp. z o.o., Warszawa

9. Moran J., Morgan M., 1989, "Meteorology the atmosphere and the science of weather". MPC New York

10. Maguire, D.J., and P.A. Longley. 2005," The emergence of geoportals and their role in spatial data infrastructures Computers", Environment and Urban Systems

11. Moran J., Morgan M., 1989, "Meteorology the atmosphere and the science of weather", MPC New York

12. "Polskie wojskowe mapy w standardach NATO (przewodnik)", 2000 - Zarząd Geografii Wojskowej, Ministerstwo Obrony Narodowej, Sztab Generalny WP, Warszawa

13. Tang, W. and Selwood, J. 2005, "Spatial Portals": Gateways to Spatial Information. ESRI Press, Redlands, CA.

14. Rusing ArcView GIS, 1996, GIS by ESRI, Environmental Systems Research Instytute, Unite States of America

15. Strefa GIS, 2013, „Geoportal zawsze pod ręka”, IMPEXGEO, Nieporęt k. Warszawy

16. Zeiler M. 1999, "Modeling Our World", Environmental System Research Instytute, Inc, California USA 